\title{
High genetic diversity and ephemeral drift effects in a successful introduced mollusc (Crepidula fornicata: Gastropoda)
}

\author{
L. Dupont*, D. Jollivet, F. Viard \\ Centre d'Études d'Océanographie et de Biologie Marine, Evolution et Génétique des Populations Marines, \\ Station Biologique de Roscoff, Centre National de la Recherche Scientifique, UMR-7127, Place Georges Teissier, BP 74, \\ 29682 Roscoff Cedex, France
}

\begin{abstract}
Human-mediated biological invasions are known to threaten biodiversity and are often the cause of economic problems, mainly via interspecific interactions with commercially valuable indigenous species. The hermaphroditic gastropod Crepidula fornicata (L.) is a successful marine invader of European coasts. In France, it was first recorded in the 1940s and now proliferates, competing with cultured and fished bivalves. To analyze the patterns of spread and the genetic architecture of the populations of this invader, 13 populations, 12 French and 1 native (American) $(\mathrm{N}=660$ ) were sexed and analyzed using 8 polymorphic enzyme loci. The majority of the populations showed balanced sex ratios. A high level of genetic diversity was detected in the French populations, contrary to the usual pattern of founder effect frequently reported for invaders. Moreover, most of the introduced populations were shown to be in migration-drift equilibrium. Thus, our results suggest that, in its introduced range, C. fornicata has stable populations and behaves genetically and demographically in the same way that it does over its native range. The pattern among French populations suggests that the introduction process was complex, and that $C$. fornicata from France derives from several genetically diverse, but poorly differentiated, source populations. Finally, this dataset also showed that the effects of shell-farmer-mediated transport between bays are only detectable at some specific localities. On the other hand, there was a good fit between patterns of genetic differentiation and the major hydrodynamic features along the French coasts, strongly suggesting that larval dispersal plays an important role in the spread of $C$. fornicata in Europe.
\end{abstract}

KEY WORDS: Biological invasion - Slipper-limpet · Founder effect · Dispersal · Genetic diversity · Protandry

\section{INTRODUCTION}

Because of their potentially dramatic ecological consequences, biological invasions (i.e. intentional or accidental spread of species across their natural dispersal barriers: Vermeij 1996) are now becoming a major issue in biodiversity conservation. Although it has been estimated that only 10 to $20 \%$ of transported species become established (Lodge 1993, Williamson 1996), successful invaders may abruptly modify the interactions among native species and may affect the stability of the whole ecosystem (Moyle \& Light 1996,
Levine \& D'Antonio 1999, Simberloff \& Von Holle 1999). In marine environments, biogeographical barriers to gene flow are breached by human-mediated movements of species (ballast water transport, aquaculture, canals), leading to a constant increase in the number of marine introductions since the beginning of the 20th century (Carlton \& Geller 1993, Ruiz et al. 1997, Carlton 1999, Reise et al. 1999).

Analysis of genetic and evolutionary processes are key features in studies of biological invasions. Through the modification of genetic characteristics and architecture in invasive populations, evolutionary forces 
such as selection or genetic drift play a major role in determining the spread and the long-term establishment of alien species (Davies et al. 1999, Sakai et al. 2001, Lee 2002). For instance, strong genetic drift effects are expected when populations are founded by a small number of colonists (Sakai et al. 2001). The genetic impact of founder events varies according to the number of founding individuals, their total genetic diversity, and the speed at which population size increases after establishment (Nei et al. 1975). Although still being debated (Amos \& Balmford 2001), it is generally accepted that the loss of genetic diversity can result in inbreeding depression and the limited ability of populations to evolve (Sakai et al. 2001). Once the introduced species become established, dispersal capacity is another key factor on which selection might act and promote the spread of the species in its introduced range (Geller 1996, Lee 2002). Dispersal strongly influences the demographic functioning, the genetic architecture, and the persistence of populations (Ferriere et al. 2000, Lee 2002).

Besides providing new insights into evolutionary processes that act during the invasion process, populationgenetic techniques can provide powerful tools for determining specific and practical aspects pivotal to successful management of invading species, namely: (1) identification of source population(s); (2) enumeration of successful introductions (i.e. introductions that effectively contribute to subsequent generations); (3) detection of selective tensions at the points of introduction that directly limit the spread of the species; (4) potential for hybridization with indigenous species. Surprisingly, as noted by Sakai et al. (2001) in their recent review, the genetics and evolution of invasive species have received far less attention than their ecology.

Among recent reported marine invaders (Carlton 1996, Reise et al. 1999), the slipper limpet Crepidula fornicata (L.), indigenous to eastern North America and first introduced into Europe in the British Isles at the end of the 19th century, is one of the best examples of a successful invasion in coastal environments. C. fornicata has invaded a large number of European bays, ports and shellfish-farming sites, where it has now attained a significant biomass (Blanchard 1997). In its native area, this species has been the subject of numerous studies on the larval development (Pechenik et al. 1996, 2001), reproductive system (Coe 1936, Hoagland 1978, Collin 1995) and systematics of the Crepidula genus (Hoagland 1984, Collin 2001). The invasion history of the slipper limpet on French coasts is welldocumented, and there is a possibility that several successful introduction events have occurred. We hypothesized that the reproductive system and the dispersal ability of $C$. fornicata are major forces driving its invasion success. First, C. fornicata displays a 2 to $4 \mathrm{wk}$ planktonic larval stage, a feature that typifies species with high rates of gene flow (Neigel 1997). Second, the spread of $C$. fornicata seems to have been facilitated by human-mediated transport between shellfishfarming sites and fishing areas. Moreover, it is a longlived protandrous hermaphrodite characterized by a strong social control of sex-change (Coe 1938, Collin 1995) by which the male:female sex ratio can be adjusted to a 1:1 ratio to maximize the effective population size.

We investigated 12 French populations typifying areas in which Crepidula fornicata proliferates. Individuals were sexed and genotyped at 8 enzyme loci. These populations were compared with 8 populations from the American native area both by screening 1 additional native population (Woods Hole, USA) and by comparing our results with those of Hoagland (1984) (7 loci in common with this study, for 7 native populations).

The present study addressed the following issues: (1) Did colonists undergo a severe founder effect which is known to cause marked reductions in genetic diversity? (2) What are the invader dynamics of expansion? (3) Which vector (human-mediated transportation or hydrodynamic conditions) plays the major role in disseminating the introduced species?

\section{MATERIALS AND METHODS}

Species distribution and sampling. Crepidula fornicata was initially accidentally introduced into Great Britain in the 1890s and early 1900s with oyster spats Crassostrea virginica transplanted from eastern North America (Hoagland 1984). Its first appearance along the French coasts of Brittany and Normandy occurred in the 1940s (Blanchard 1995). The cause for this introduction is unknown (Blanchard 1995); it could have been either an introduction from Great Britain or from the USA. A second invasion phase was reported in the 1970s on the Atlantic coast of France with the introduction of adults of the Japanese oyster Crassostrea gigas from British Columbia (Canada), where C. fornicata was also accidentally introduced. C. fornicata subsequently extended over most European bays and estuaries and is now widely distributed from the North Sea to the Mediterranean Sea (Blanchard 1997).

The presence of the filter-feeding Crepidula fornicata has major consequences for indigenous macrobenthic fauna and their habitat. In some French bays it is now very abundant; for example, reports of $250000 \mathrm{t}$ in the Bay of St. Brieuc (Hamon 1996); $18500 \mathrm{t}$ in the Bay of Brest (Chauvaud 1998) and $5000 \mathrm{t}$ in the Bay of Marennes-Oléron (Sauriau et al. 1998). In such large numbers, C. fornicata extensively modifies the substra- 
tum composition by increasing mud sedimentation (Erhold et al. 1998). In addition, it is a spatial (and probably trophic) competitor with some commercially important filter-feeding species (e.g. Crassostrea gigas, Pecten sp.; de Montaudouin et al. 1999).

Crepidula fornicata samples were collected from 12 sites in France (Fig. 1) and 1 site in the northern part of its native distribution (Woods Hole, USA). The sampling scheme is representative of the distribution of the slipper limpet in France (Blanchard 1995). Samples (51 specimens per population on average) were collected after the reproductive summer period from October 2000 to May 2001. Upon collection, individuals were frozen at $-80^{\circ} \mathrm{C}$ or in liquid nitrogen.

Sex ratio. The slipper limpet is a sequential protandrous hermaphrodite (i.e. mature individuals are first males and then change into females: Coe 1936). Individuals form semi-permanent stacks in which small (young) males attach to the shells of larger (older) females. Sex change in Crepidula fornicata is said to be environmentally determined (Heller 1993) and is strongly influenced by individual associations with conspecifics (Collin 1995). All individuals were sexed; the sexual morphs were determined according to presence or absence of penis. Immature individuals that lack a penis are usually small (i.e. less than $15 \mathrm{~mm}$ in size: Coe 1936) and situated at the top of a stack. Transitional individuals display an aborted penis and are found in the middle of the stack between true males and females. Sex distribution was calculated for each local population and over all the French populations. Departures from a 1:1 sex ratio were tested using a chi-square test.

Isozyme assays. The cephalic part of the frozen slipper limpet was homogenized in a grinding solution (0.01 M Tris, 0.002 M EDTA, 0.05\% $\beta$-mercaptoethanol, $0.0001 \mathrm{M}$ phenylmethylsulphonyl fluoride, $0.25 \mathrm{M}$ sucrose; $\mathrm{pH}$ 6.8). After centrifugation at $13500 \times g$ for $25 \mathrm{~min}$, the supernatant was stored at $-20^{\circ} \mathrm{C}$ until subjected to starch-gel electrophoresis. Following Hoagland (1984), 11 isozyme systems were surveyed; 8 loci ( 7 enzymes) were found to be consistently interpretable and were scored for all populations (see Table 1). Electrophoresis conditions followed those of Hoagland (1984). Loci were numbered according to the decreasing anodal electromorph mobility in multiloci systems, and alleles were assigned according to their relative distance to the most frequent allele (100) in populations.

Statistical analyses. Genetic diversity, differentiation and structure were estimated as follows:

Genetic diversity in native and introduced populations: For the studied populations, allele frequencies, the total number of alleles, the average number of alleles $\left(N_{\text {all }}\right)$, the observed $\left(H_{0}\right)$ and expected $\left(H_{\mathrm{e}}\right)$ hetero-

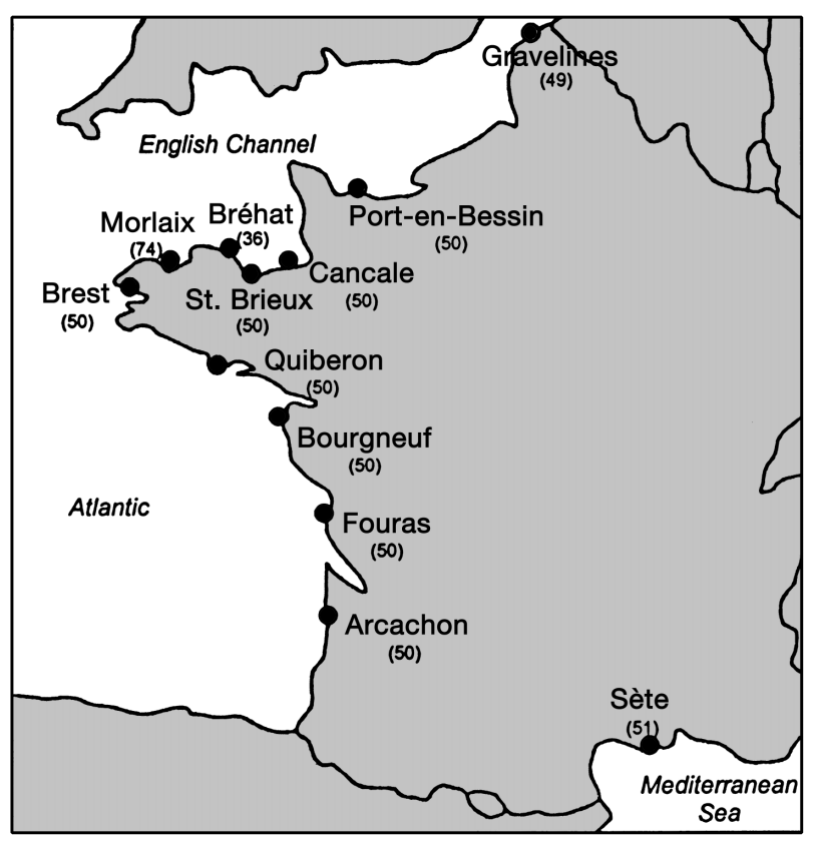

Fig. 1. Crepidula fornicata. Location map of 12 populations studied in French introduction area. Number of individuals analyzed within each population is indicated in parentheses

zygozities were estimated using Genetix V4.01 (Belkhir et al. 2000).

The null hypothesis of independence between loci was tested from statistical genotypic disequilibrium analysis using Genepop V3.3 (Raymond \& Rousset 1995a).

Departures from expected diversities in introduced populations: Tests for deviations from Hardy-Weinberg expectations were carried out within each population using Genepop V3.3 (Raymond \& Rousset 1995a). For loci with $<5$ alleles, an exact $p$-value was calculated using a complete enumeration method (contingency tables). In other cases, the exact p-value was estimated without bias by the Markov chain (Guo \& Thompson 1992) with 2000 batches and 2000 iterations per batch. Departures from Hardy-Weinberg expectations within populations were quantified by calculating the Weir \& Cockerham's (1984) $\hat{f}$ estimator (a monolocus estimator of the fixation index $F_{\text {is, }}$ correlation of genes within individuals with respect to genes between individuals within populations) with Genepop V3.3 (Raymond \& Rousset 1995a).

Given that populations of Crepidula fornicata have been recently introduced (<70 yr ago), demographic disequilibria are expected (either persistent founder effect or population in expansion). Recently founded populations display a transient Hardy-Weinberg gene diversity $\left(H_{\mathrm{e}}\right)$ excess when compared to the gene diver- 
sity computed from the observed number of alleles at the mutation-drift equilibrium $\left(H_{\text {eq }}\right)$ under the assumption of a constant-size population (Maruyama \& Fuerst 1984, Luikart et al. 1998). In contrast, an expanding population (e.g. one recovering from a bottleneck) is characterized by a transient decrease in $H_{\mathrm{e}}$ compared to $H_{\text {eq }}$ (Cornuet \& Luikart 1996, Luikart et al. 1998). To test for such a deviation, a Wilcoxon test from the software Bottleneck (Cornuet \& Luikart 1996) was used following the recommendations of Cornuet \& Luikart (1996).

Genetic differentiation between populations in area of introduction: Given that oyster spats are transported between Atlantic, Channel and Mediterranean aquaculture sites and could be infested by young slipper limpets, we were interested in the relative impact of shell-farming on the dispersal of Crepidula fornicata. To this end, we analyzed the genetic structure among introduced populations. Genetic differentiation among all populations and between pairs of populations was estimated using Genepop V3.3 by calculating $\hat{\theta}$, the Weir \& Cockerham (1984) estimator of $F_{\mathrm{st}}$ (Wright 1951). An unbiased estimate of the probability that $F_{\text {st }}$ (correlation of genes within populations with respect to genes between populations) values depart significantly from zero was calculated through a 2000iteration Markov chain-permutation procedure to test for differences in allelic distributions between pairs of populations.

The isolation-by-distance model offers a means of testing patterns of dispersal using pairwise combinations of populations (Slatkin 1993). Coastline geographical distances were measured from a map and plotted against $\hat{\theta} /(1-\hat{\theta})$ estimates to compute a linear relationship following the recommendations of Rousset (1997). A Mantel-like permutation procedure was then used to test for the null hypothesis of independence between genetic and geographic distances (Genepop V3.3).

An $F_{\text {st }}$-based hierarchical AMOVA (analysis of molecular variance: Excoffier et al. 1992) which partitions the molecular variance into 3 components (i.e. variation among groups, among populations within a group and among populations between groups) was used to test for regional structure of populations. Groups were chosen on a natural geographical basis that reflected the major oceanic currents. The Western Channel entrance (Iroise Sea) acts as a hydrodynamic barrier, with 2 major currents: one extending to the northwestern part of the English Channel and the other drifting to the south Atlantic part of the French coasts (Lazure \& Salomon 1991, Salomon \& Breton 1991). In addition, some strong gyres play an important role in the residence time of particles in the Channel Islands region (Salomon \& Breton 1991) situated at the western boundary of the English Channel. Consequently, 3 groups were defined as: (1) a 'North' group comprising the eastern English Channel populations (Gravelines and Port-en-Bessin), (2) a 'Channel' group comprising the western English Channel populations (St. Brieuc, Cancale, Brehat, Morlaix and Brest), and (3) an 'Atlantic' group comprising Quiberon, Bourgneuf, Fouras and Arcachon. The population of Sète was excluded from the analysis since it represents a unique Mediterranean sample.

Average gene diversity and genetic structure comparisons between native and introduced populations: Using 7 of the loci employed in the present study, Hoagland (1984) surveyed, 7 native populations, including 1 population from Woods Hole (i.e. the same location as the native population sampled for the present study). As the genotypic composition was unknown and the exact allelic correspondence was ambiguous, we chose to use estimated parameters and statistical results rather than the allelic frequencies for comparison between the 2 studies. The 2 samples from Woods Hole (1981: Hoagland 1984; 2001: our dataset) were compared according to Nei \& Kumar (2000) to determine whether gene diversities differed temporally at this location in the native area. The absence of significant differences allowed comparisons of the genetic diversity between our introduced French populations with Hoagland's (1984) native populations.

To compare the overall genetic structure between both the native and introduced populations, a global $F_{\text {st }}$ among native populations was calculated from allelic frequencies provided by Hoagland (1984) using the software BIOSYS (Swofford \& Selander 1989). An exact test of differentiation among samples (Raymond \& Rousset 1995b) from the software Arlequin V2.0 (Schneider et al. 2000) was used to evaluate the null hypothesis $F_{\text {st }}=0$ for single-locus $F_{\text {st }}$ values. An overall test for significance combining probabilities from exact tests was carried out according to Fisher (1954) following the recommendations given by Sokal \& Rohlf (1995).

\section{RESULTS}

\section{Distribution of sexual morphs}

The overall sex ratio of the French populations Crepidula fornicata was balanced: $46 \%$ of individuals were female and $46 \%$ were males ( $8 \%$ were in a transitional 'hermaphrodite' stage). At the single population level, only 2 populations departed significantly from a 1:1 sex ratio (Fig. 2): the Sète population display an excess of females $\left(\chi^{2}=9.68,1 \mathrm{df}, \mathrm{p}<0.005\right)$ and the Quiberon population an excess of males $\left(\chi^{2}=7.68,1 \mathrm{df}\right.$, 
$p<0.01$ ). The low percentage of males at the first site may be due to a low reproduction rate in the Mediterranean area where the slipper limpet is not wellestablished (Wilczynski 1955, Hoagland 1978, Le Gall 1980). At the second site, the male excess could be due to the arrival of a huge amount of recruits through active reproduction. Hoagland (1978) reported a similar excess of males $(73 \%)$ at the same period (May) in the newly founded population of Rhode Island $(<3 \mathrm{yr}$ old) (Fig. 2). The sex ratio of 10 of the French populations was close to that of the native population of Woods Hole $(41 \%$ females vs $55 \%$ males in 2001 and $54 \%$ males in 1972: Fig. 2).

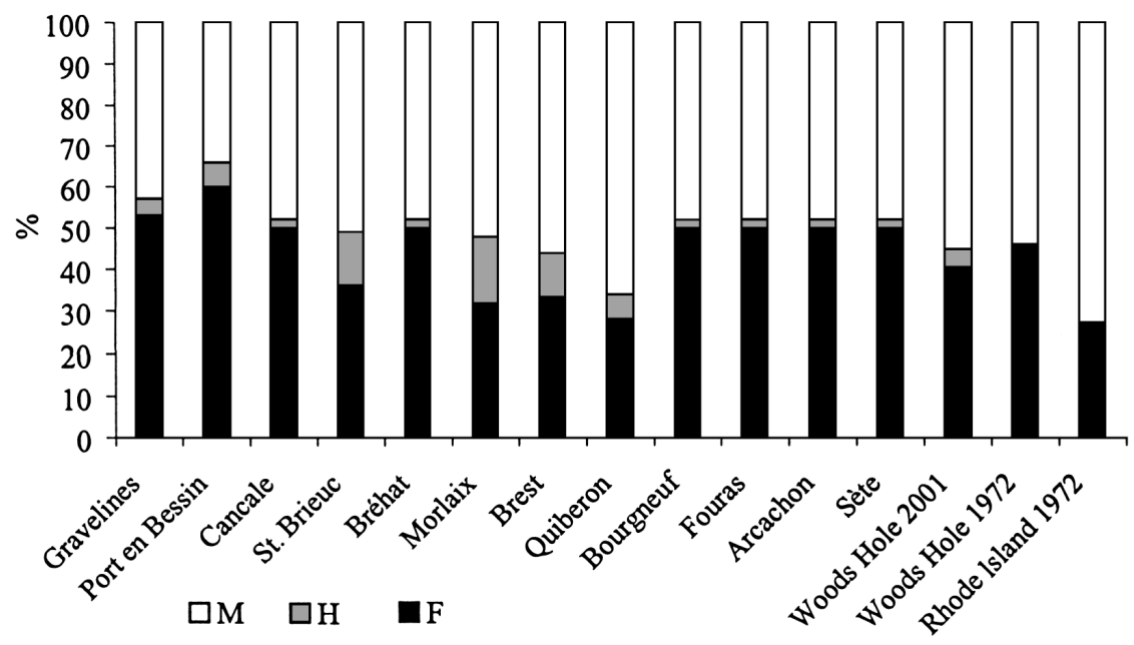

Fig. 2. Crepidula fornicata. Sexual morph frequencies within studied populations and within native USA populations. M: males; F: females; H: hermaphrodites. (No sexual intermediates were reported for 1972 populations by Hoagland 1978)

\section{Overall enzymatic polymorphism}

The polymorphic loci screened had from 2 to 5 alleles, with an average of $4.1(\mathrm{SD}=1.1)$. However, most loci analyzed displayed unbalanced allele frequencies with 1 or 2 predominant alleles and a few rare alleles (allelic frequencies are available from the authors on request; summary statistics are given in Table 1). The genetic diversity was variable among loci $\left(H_{\mathrm{e}}\right.$ values ranged from 0.01 for Est-1 to 0.51 for Pgm; Table 1). No genotypic disequilibrium was detected, indicating that the loci were independent.

\section{Genetic diversity in introduced populations}

Summary statistics of within-population genetic diversity are presented in Table 2 . The average number of alleles per locus and the expected gene diversity were comparable among all introduced populations. No significant correlation was observed between genetic diversity and the approximate date of introduction (i.e. first report in the literature) either for $N_{\text {all }}\left(r^{2}=0.05 ; \mathrm{p}=0.48\right)$ or $H_{\mathrm{e}}\left(\mathrm{r}^{2}=0.006 ; \mathrm{p}=0.81\right)$.

Five populations (Port-en-Bessin, St. Brieuc, Bréhat, Morlaix and Fouras) showed significant departures from Hardy-Weinberg proportions caused by a deficiency in heterozygotes (Table 2). However, these deficiencies involved only 3 loci (Pep-2, Mdh2 and Pgm). No disequilibrium was observed for any of these loci.

These results may be due to either a Wahlund effect or recurrent inbreeding.

When testing for deviation from the mutation-drift equilibrium, a significant gene diversity excess was

Table 1. Crepidula fornicata. Estimates of polymorphism at allozyme loci in the present study $N_{\text {tall }}, N_{\text {all(loc), }} H_{\text {e(loc) }}$ : total number of alleles, average number of alleles and average gene diversity respectively. These statistics were estimated for each locus over all 13 populations $\left(N_{\text {ind }}=660\right)$

\begin{tabular}{|c|c|c|c|c|c|}
\hline Enzyme & Locus & & $N_{\text {tall }}$ & $\begin{array}{l}N_{\text {all(loc) }} \\
\text { (SD) }\end{array}$ & $\begin{array}{c}H_{\mathrm{e}(\text { loc })} \\
\text { (SD) }\end{array}$ \\
\hline AAT & $\begin{array}{l}\text { Aspartate amino transferase } \\
\text { (EC.2.61.1) }\end{array}$ & Aat & 4 & $\begin{array}{l}2.15 \\
(1.07)\end{array}$ & $\begin{array}{c}0.04 \\
(0.04)\end{array}$ \\
\hline EST & $\begin{array}{l}\text { Esterase NA } \\
\text { (EC.3.11.1) }\end{array}$ & Est-1 & 2 & $\begin{array}{l}1.31 \\
(0.48)\end{array}$ & $\begin{array}{c}0.01 \\
(0.01)\end{array}$ \\
\hline Leu-tyr & $\begin{array}{l}\text { Peptidase } \\
\text { (Leucine-tyrosine) }\end{array}$ & Pep-2 & 3 & $\begin{array}{c}2.85 \\
(0.38)\end{array}$ & $\begin{array}{c}0.29 \\
(0.14)\end{array}$ \\
\hline $\mathrm{MDH}$ & $\begin{array}{l}\text { NAD-dependent } \\
\text { malate deshydrogenase } \\
\text { (EC.1.11.37) }\end{array}$ & $\begin{array}{l}\text { Mdh-1 } \\
\text { Mdh-2 }\end{array}$ & $\begin{array}{l}5 \\
4\end{array}$ & $\begin{array}{c}3.54 \\
(0.88) \\
1.77 \\
(0.83)\end{array}$ & $\begin{array}{c}0.29 \\
(0.10) \\
0.04 \\
(0.05)\end{array}$ \\
\hline MPI & $\begin{array}{l}\text { Mannose-6-phosphate isomerase } \\
\text { (EC.5.31.8) }\end{array}$ & Mpi-2 & 5 & $\begin{array}{c}3.61 \\
(0.87)\end{array}$ & $\begin{array}{c}0.15 \\
(0.09)\end{array}$ \\
\hline PGI & $\begin{array}{l}\text { Phosphogluco-isomerase } \\
\text { (EC.5.31.9) }\end{array}$ & Pgi & 5 & $\begin{array}{l}3.54 \\
(0.66)\end{array}$ & $\begin{array}{c}0.49 \\
(0.05)\end{array}$ \\
\hline PGM & $\begin{array}{l}\text { Phosphoglucomutase } \\
\text { (EC.2.75.1) }\end{array}$ & Pgm & 5 & $\begin{array}{l}4.15 \\
(0.55)\end{array}$ & $\begin{array}{c}0.51 \\
(0.06)\end{array}$ \\
\hline
\end{tabular}


Table 2. Crepidula fornicata. Genetic diversity and heterozygote deficiency within populations. Shown are locality (date of collection); total number of individuals per population $(\mathrm{N})_{\text {; }}$ date of first report of presence of $C$. fornicata (First record); $N_{\text {all }}, H_{\mathrm{o}}, H_{\mathrm{e}}$ (mean \pm SD number of alleles over loci and observed and expected heterozygosities respectively); multilocus estimator $(\hat{f})$ of the fixation index $F_{\text {is }}$ (where bold-face indicates significant departure from Hardy-Weinberg proportions); and exact probability ( $\left.\mathrm{p}_{\mathrm{HW}}\right)$

\begin{tabular}{|c|c|c|c|c|c|c|c|c|c|c|c|}
\hline \multirow[t]{2}{*}{ Population } & \multirow[t]{2}{*}{ (Date) } & \multirow[t]{2}{*}{$\mathrm{N}$} & \multirow{2}{*}{$\begin{array}{l}\text { First } \\
\text { record }\end{array}$} & \multicolumn{2}{|c|}{$N_{\text {all }}$} & \multicolumn{2}{|c|}{$\mathrm{H}_{\mathrm{o}}$} & \multicolumn{2}{|l|}{$\mathrm{H}_{\mathrm{e}}$} & \multirow[t]{2}{*}{$\hat{f}$} & \multirow{2}{*}{$\mathrm{p}_{\mathrm{HW}}$} \\
\hline & & & & Mean & $\mathrm{SD}$ & Mean & $\mathrm{SD}$ & Mean & $\mathrm{SD}$ & & \\
\hline Gravelines & (May 01) & 49 & $1963^{\mathrm{a}}$ & 3.13 & 1.64 & 0.248 & 0.239 & 0.251 & 0.238 & 0.012 & 0.832 \\
\hline Port en Bessin & (Jun 01) & 50 & $1945^{\mathrm{b}}$ & 2.63 & 0.92 & 0.195 & 0.183 & 0.224 & 0.212 & 0.128 & 0.002 \\
\hline Cancale & (Mar 01) & 50 & $1976^{\mathrm{b}}$ & 3.00 & 1.41 & 0.214 & 0.225 & 0.222 & 0.232 & 0.036 & 0.601 \\
\hline St. Brieuc & (Apr 01) & 50 & $1974^{\mathrm{c}}$ & 2.88 & 1.25 & 0.200 & 0.198 & 0.221 & 0.213 & 0.094 & 0.029 \\
\hline Bréhat & (Mar 01) & 36 & $1960^{b}$ & 2.50 & 0.93 & 0.192 & 0.232 & 0.205 & 0.205 & 0.067 & 0.005 \\
\hline Morlaix & (Oct 00) & 74 & $1960^{b}$ & 3.25 & 1.17 & 0.210 & 0.212 & 0.232 & 0.222 & 0.098 & 0.015 \\
\hline Brest & (Mar 01) & 50 & $1949^{\mathrm{d}}$ & 2.50 & 0.93 & 0.200 & 0.232 & 0.203 & 0.225 & 0.015 & 0.123 \\
\hline Quiberon & (Apr 01) & 50 & $1963^{\mathrm{a}}$ & 2.88 & 1.25 & 0.225 & 0.173 & 0.247 & 0.210 & 0.091 & 0.519 \\
\hline Bourgneuf & (May 01) & 50 & $1963^{\mathrm{a}}$ & 2.88 & 1.46 & 0.229 & 0.190 & 0.248 & 0.206 & 0.077 & 0.236 \\
\hline Fouras & (Apr 01) & 50 & $1972^{\mathrm{e}}$ & 3.25 & 1.04 & 0.217 & 0.206 & 0.230 & 0.196 & 0.060 & 0.033 \\
\hline Arcachon & (Mar 01) & 50 & $1969^{f}$ & 2.63 & 1.30 & 0.200 & 0.191 & 0.207 & 0.207 & 0.033 & 0.899 \\
\hline Sète & (May 01) & 51 & $1982^{\mathrm{b}}$ & 3.13 & 1.36 & 0.206 & 0.185 & 0.225 & 0.192 & 0.082 & 0.245 \\
\hline Mean (French) & & & - & 2.89 & 0.27 & 0.211 & 0.016 & 0.226 & 0.016 & - & - \\
\hline Woods Hole (USA) & (May 01) & 50 & native & 2.63 & 1.30 & 0.253 & 0.247 & 0.255 & 0.243 & 0.005 & 0.165 \\
\hline
\end{tabular}

detected for 2 populations: Cancale and Fouras (Wilcoxon test: $\mathrm{p}=0.027$ and $\mathrm{p}=0.019) ; 2$ other populations (Bréhat and Morlaix) also displayed probability values very close to the rejection threshold of $5 \%(p=$ 0.055), and may therefore also be good candidates for recent demographic disequilibrium as this test is not very powerful with a low number of loci. The fact that 3 of these populations displayed a significant heterozygote deficiency (Bréhat, Morlaix and Fouras) supports a population expansion hypothesis.

\section{Gene flow and dispersal among introduced populations}

The global test for genetic differentiation among populations revealed significant heterogeneity in allele frequencies among the 12 French populations $(\hat{\theta}=$ 0.022, $\mathrm{p}=0.000$ ).

Genetic differentiation was estimated between the groups: North, Channel and Atlantic (Table 3). An AMOVA showed that, although no significant genetic heterogeneity was observed among these groups (genetic differentiation of populations between groups, $F_{c t}=0.003$, $\mathrm{p}=0.058)$, the Channel group differed from the 2 other groups $\left(F_{\mathrm{ct}}=0.011, \mathrm{p}=0.000\right.$ and $\left.F_{\mathrm{ct}}=0.069, \mathrm{p}=0.000\right)$. In contrast, the North and Atlantic groups were not significantly differentiated $\left(F_{\mathrm{ct}}=0.001, \mathrm{p}=0.275\right)$. Geographically closely related groups (North and Channel; Atlantic and Channel) were genetically differentiated despite transfers of oyster spats between bays. As rare alleles may affect the overall pattern observed, these analyses were
Table 3. Crepidula fornicata. Hierarchical analysis of molecular variance in 3 groups examined, North $(\bullet)$ : Gravelines, Port en Bessin;

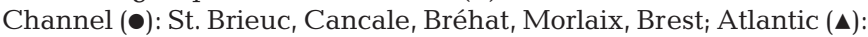
Quiberon, Fouras, Arcachon, Bourgneuf. $F_{\mathrm{ct}}, F_{\mathrm{sc},} F_{\mathrm{st}}$ : genetic differentiation between groups, genetic differentiation between populations within groups and genetic differentiation between populations respectively. Bold-face indicates significant values

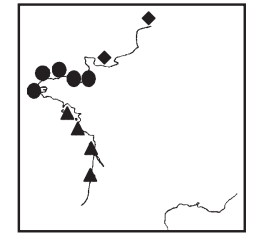

\begin{tabular}{|lccc|}
\hline Source of variation & \% of variation & Fixation indice & p-value \\
\hline North, Channel and Atlantic & & & \\
$\quad$ Among groups & 0.29 & $F_{\text {ct }}=0.003$ & 0.058 \\
$\quad$ Among populations within groups & 0.48 & $\boldsymbol{F}_{\text {sc }}=\mathbf{0 . 0 0 5}$ & 0.032 \\
$\quad$ Within populations & 99.23 & $\boldsymbol{F}_{\text {st }}=\mathbf{0 . 0 0 8}$ & 0.001 \\
North and Channel & & & \\
$\quad$ Among groups & 6.86 & $\boldsymbol{F}_{\text {ct }}=\mathbf{0 . 0 6 9}$ & 0.000 \\
$\quad$ Among populations within groups & 0.42 & $\boldsymbol{F}_{\text {sc }}=\mathbf{0 . 0 0 5}$ & 0.050 \\
$\quad$ Within populations & 92.71 & $\boldsymbol{F}_{\text {st }}=\mathbf{0 . 0 7 3}$ & 0.000 \\
Channel and Atlantic & & & \\
$\quad$ Among groups & 1.15 & $\boldsymbol{F}_{\mathrm{ct}}=\mathbf{0 . 0 1 1}$ & 0.000 \\
$\quad$ Among populations within groups & 0.51 & $\boldsymbol{F}_{\text {sc }}=\mathbf{0 . 0 0 5}$ & 0.019 \\
$\quad$ Within populations & 98.34 & $\boldsymbol{F}_{\mathrm{st}}=\mathbf{0 . 0 1 7}$ & 0.000 \\
North and Atlantic & & & \\
$\quad$ Among groups & 0.07 & $F_{\text {ct }}=0.001$ & 0.275 \\
$\quad$ Among populations within groups & 0.39 & $F_{\text {sc }}=0.004$ & 0.181 \\
$\quad$ Within populations & 99.54 & $F_{\text {st }}=0.005$ & 0.113 \\
\hline
\end{tabular}


Table 4. Crepidula fornicata. Pairwise multi-loci $\hat{\theta}$ estimates (below diagonal) and geographic distance (km, above diagonal) for each pair of populations. Exact test of allelic differentiation: ${ }^{*} \mathrm{p}<0.05 ;{ }^{* *} \mathrm{p}<0.01 i^{* * *} \mathrm{p}<0.001$

\begin{tabular}{|c|c|c|c|c|c|c|c|c|c|c|c|}
\hline & Gravelines & $\begin{array}{l}\text { Port en } \\
\text { Bessin }\end{array}$ & Cancale & St. Brieuc & Bréhat & Morlaix & Brest $G$ & Quiberon $\mathrm{E}$ & Bourgneuf & Fouras & Arcachon \\
\hline Gravelines & - & 340 & 640 & 940 & 990 & 1105 & 1245 & 1545 & 1715 & 1890 & 2065 \\
\hline Port en Bessin & $n-0.001$ & & 300 & 415 & 455 & 570 & 710 & 1010 & 1180 & 1355 & 1530 \\
\hline Cancale & $0.085^{* * *}$ & $0.076^{* * *}$ & & 115 & 165 & 280 & 420 & 720 & 890 & 1065 & 1240 \\
\hline St. Brieuc & $0.052^{* * *}$ & $0.050^{* * *}$ & $0.007^{*}$ & & 50 & 165 & 305 & 600 & 770 & 945 & 1120 \\
\hline Bréhat & $0.062^{* * *}$ & $0.055^{* * *}$ & $0.008^{*}$ & -0.008 & & 115 & 255 & 555 & 725 & 900 & 1075 \\
\hline Morlaix & $0.073^{* * *}$ & $0.067^{* * *}$ & $0.001^{*}$ & $0.007^{* * *}$ & 0.004 & & 140 & 440 & 610 & 785 & 960 \\
\hline Brest & $0.067^{* * *}$ & $0.066^{* * *}$ & $0.009^{*}$ & $0.013^{* * *}$ & $0.013^{*}$ & 0.000 & & 300 & 470 & 645 & 820 \\
\hline Quiberon & $0.050^{* * *}$ & $0.045^{* * *}$ & $0.011^{* * *}$ & $0.008^{* * *}$ & $0.012^{* * *}$ & $0.018^{* * *}$ & $0.026^{* * *}$ & $* * \quad 500$ & 170 & 345 & 520 \\
\hline Bourgneuf & 0.010 & 0.006 & $0.030^{* * *}$ & $0.015^{* * *}$ & $0.021^{* * *}$ & $0.026^{* * *}$ & $0.024^{* * *}$ & 0.010 & ron & 175 & 350 \\
\hline Fouras & $0.036^{* *}$ & $0.030^{* * *}$ & $0.012^{* *}$ & $0.006^{*}$ & $0.008^{* *}$ & $0.009^{* *}$ & 0.011 & -0.002 & 0.001 & & 175 \\
\hline Arcachon & $0.042^{* * *}$ & $0.036^{*}$ & 0.013 & 0.001 & 0.004 & $0.010^{* * *}$ & $0.005^{*}$ & $0.016^{*}$ & 0.004 & 0.005 & \\
\hline Sète & $0.032^{* *}$ & $0.028^{* * *}$ & $0.019^{* * *}$ & $0.003^{*}$ & $0.006^{* *}$ & $0.020^{* * *}$ & $0.024^{* * *}$ & 0.006 & -0.001 & $0.001^{*}$ & 0.006 \\
\hline
\end{tabular}

also run pooling rare alleles. The same results were found.

Within the Atlantic group, no genetic differentiation $(\hat{\theta}=0.006, p=0.23)$ and no pattern of isolation-bydistance $(p=0.38)$ were observed, whereas a slight but significant level of genetic differentiation $(\hat{\theta}=0.005$, $\mathrm{p}=0.000)$ and a pattern of isolation-by-distance $(\mathrm{p}=$ 0.02) was detected within the Channel group. The 2 populations of the North group were genetically very close $(\hat{\theta}=-0.001, \mathrm{p}=0.34)$.

To investigate with accuracy how genetic variance was distributed between the introduced populations, genetic differentiation between all population pairs was analyzed: $71 \%$ of $\hat{\theta}$ values (47 out of 66 ) were significant at the $5 \%$ threshold (Table 4 ); of these, $41 \%$ remained significant after applying a sequential Bonferroni correction (Rice 1989). Within groups, the geographically closest pairs of populations were also genetically identical, except for the Cancale/St Brieuc pair. Other pairs of genetically identical populations were surprising, having regard to their geographical position. This was especially the case with Arcachon and Sète; with Bourgneuf and Gravelines or Port en Bessin; and with Arcachon and Cancale, St. Brieuc or Bréhat.

Genetic differentiation was also observed between the North populations and all the remaining populations, except Bourgneuf. The genetic differentiation of the North group is well illustrated by the isolation-by-distance curve in Fig. 3. A significant global pattern of isolation-by-distance was mostly due to the genetic isolation of the North populations. No pattern of isolation-by-distance was observed when the North populations were excluded from the analysis $(p=0.34)$.

\section{Comparison between introduced and native populations}

First, we checked whether genetic diversity of introduced populations was comparable with that of native populations (Hoagland 1984) by testing the difference of gene diversity means between the 2 samples we had in common (Woods Hole 1981 and 2001). As no significant differences between these gene diversity means were observed (Table 5; 2-tailed test, $t_{(5)}=0.257,0.9<$ $\mathrm{p}<0.5$ ), one can conclude that the 2 studies were comparable.

The results from statistical tests used to compare native and introduced populations are summarized in Table 5. A higher number of alleles was observed in the native populations at 4 loci. This may be due to a larger sampling size in the native area (native $\mathrm{N}=$ $62.4 \pm 12.2$ vs introduced $N=50.3 \pm 7.8$ ). However, over the 7 loci, the observed number of alleles per population $\left(N_{\text {all }}\right)$ was similar between native and introduced populations.

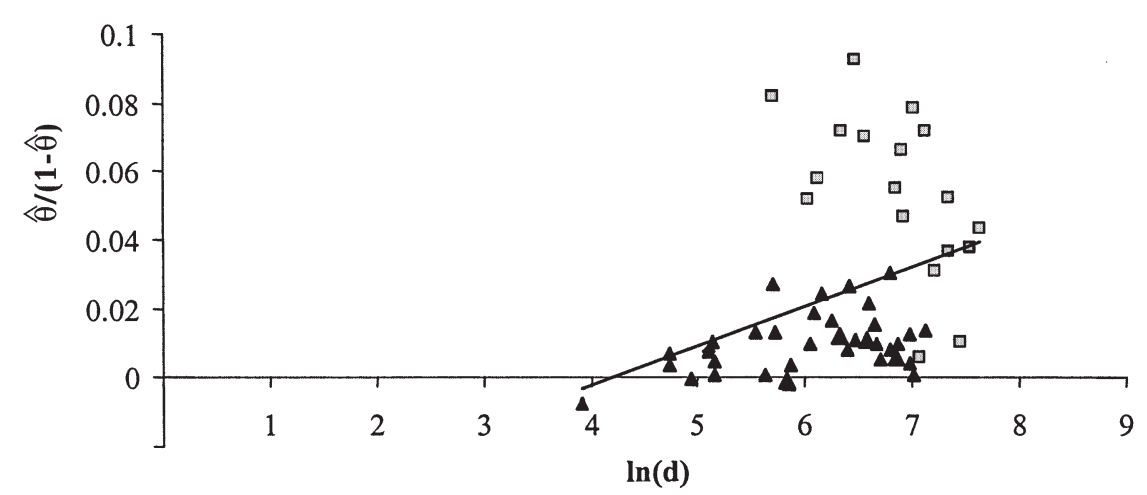

Fig. 3. Crepidula fornicata. Isolation-by-distance graph showing pairwise genetic distances $\hat{\theta} /(1-\hat{\theta})(\mathbf{\Lambda})$ plotted against geographic distances (ln [d]). 口: Differentiation population pairs including 1 of the 2 North populations; p-value (Mantel's unilateral test: correlation $>$ observed correlation $=0.01$ ) 
Table 5. Crepidula fornicata. Comparisons of genetic diversity between 13 populations analyzed in present study (12 introduced populations and 1 native population named Woods Hole 2001) and 7 native populations studied by Hoagland (1984) (the population named Woods Hole 1981 and 6 other American populations) showing total number of alleles observed over all loci $\left(N_{\text {tall }}\right)$, average number of alleles observed per population $\left(N_{\mathrm{all}}\right)$ and average gene diversity $\left(H_{\mathrm{e}}\right)$. For the 7 American populations studied by Hoagland (1984), $N_{\text {all }}$ and $\mathrm{H}_{\mathrm{e}}$ have been calculated from allelic frequencies given in her appendix. $N_{\text {pop }}, N_{\text {ind }}$ : number of populations and number of individuals respectively

\begin{tabular}{|c|c|c|c|c|c|c|c|c|c|c|}
\hline & & Aat & Est-1 & Pgi & Mpi & $M d h-1$ & $M d h-2$ & Pgm & Mean & $\mathrm{SD}$ \\
\hline \multicolumn{11}{|l|}{ Introduced } \\
\hline \multirow[t]{4}{*}{$N_{\text {ind }}=610$} & $N_{\text {all }}$ & 2.16 & 1.33 & 3.50 & 3.58 & 3.67 & 1.83 & 4.17 & 2.89 & (1.09) \\
\hline & $\mathrm{SD}$ & 1.12 & 0.49 & 0.67 & 0.90 & 0.78 & 0.84 & 0.58 & & \\
\hline & $H_{\mathrm{e}}$ & 0.040 & 0.007 & 0.494 & 0.135 & 0.305 & 0.044 & 0.504 & 0.219 & $(0.216)$ \\
\hline & $\mathrm{SD}$ & 0.039 & 0.011 & 0.052 & 0.065 & 0.083 & 0.056 & 0.054 & & \\
\hline \multicolumn{11}{|c|}{ Woods Hole (2001) } \\
\hline \multirow[t]{2}{*}{$N_{\text {ind }}=50$} & $N_{\text {all }}$ & 2 & 1 & 4 & 4 & 2 & 1 & 4 & 2.57 & $(1.40)$ \\
\hline & $H_{\mathrm{e}}$ & 0.040 & 0.000 & 0.477 & 0.378 & 0.114 & 0.000 & 0.609 & 0.231 & $(0.252)$ \\
\hline \multicolumn{11}{|c|}{ Woods Hole (1981) } \\
\hline \multirow[t]{2}{*}{$N_{\text {ind }}=48$} & $N_{\text {all }}$ & 2 & 2 & 5 & 2 & 2 & 1 & 3 & 2.43 & $(1.27)$ \\
\hline & $H_{\mathrm{e}}$ & 0.040 & 0.116 & 0.676 & 0.217 & 0.040 & 0.000 & 0.434 & 0.218 & $(0.251)$ \\
\hline \multicolumn{11}{|c|}{ Native (USA) Hoagland (1984) } \\
\hline$N_{\text {pop }}=7$ & $N_{\text {tall }}$ & 4 & 5 & 6 & 4 & 6 & 7 & 4 & & \\
\hline \multirow[t]{4}{*}{$N_{\text {ind }}=437$} & $N_{\text {all }}$ & 2.14 & 2.71 & 4.43 & 2.14 & 2.57 & 2.71 & 3.43 & 2.88 & $(0.81)$ \\
\hline & $\mathrm{SD}$ & 1.07 & 0.76 & 0.98 & 0.69 & 1.13 & 1.25 & 0.53 & & \\
\hline & $H_{\mathrm{e}}$ & 0.093 & 0.116 & 0.452 & 0.085 & 0.049 & 0.163 & 0.284 & 0.177 & $(0.143)$ \\
\hline & $\mathrm{SD}$ & 0.109 & 0.044 & 0.182 & 0.072 & 0.040 & 0.154 & 0.119 & & \\
\hline
\end{tabular}

The average value of gene diversity in the populations analyzed by Hoagland (1984) $\left(H_{\mathrm{e}}=0.177\right)$ was lower than those of the French populations $\left(H_{\mathrm{e}}=\right.$ $0.219) ; 4$ loci showed higher gene diversity values in the introduced as compared to native populations. Nevertheless, this difference was not significant (1tailed test, $t_{(6)}=1.15,0.4<\mathrm{p}<0.2$ ).

Consequently, it is apparent that genetic diversity in the newly colonized areas was similar to or even higher than that in the native area. Moreover, when a founding effect is suspected, enhanced genetic differentiation is expected inside the introduced area. However, in the native area estimates of significant genetic structure were roughly similar to or even higher than $\left(F_{\text {st }}=0.053 ; \mathrm{p}<0.05\right)$ those in the area of introduction $(\hat{\theta}=0.022)$.

\section{DISCUSSION}

Invasive species are biological models of particular interest for evolutionary biology studies as the introduction of a new species may lead to a rapid evolutionary change in the new species as well as in the resident species. Recently, Lee (2002) outlined the main issues relating to the evolutionary genetics of invasive species. Among them, genetic drift and natural selection were suggested to be the major forces modifying genetic architecture, and thus the major forces influ- encing the adaptation of the new species to its new habitat. Here, we have focused on the study of putatively neutral markers, and one of the aspects addressed was the potential role of founder events in modifying the genetic architecture of an invasive species in its newly colonized area compared to its native range. Indeed, an initial small population size is generally known to result in stochastic genetic changes due to founder effects. Because of the loss of rare alleles, this effect should cause a decrease in heterozygosity and a rapid change of allele frequencies (Hartl \& Clark 1997, Hedrick 2000). Although the potential evolutionary effects of founder events are considerable, it is not clear how important they are in real populations (Barton \& Charlesworth 1984, Johnson 1988).

Since populations which have lost considerable variation have a high risk of becoming extinct, it is likely that a successful invader is not subject to a sufficiently severe founder effect to cause a marked reduction in variation (Barton \& Charlesworth 1984). Nevertheless, founder effects have been regularly reported for many of the invasive species investigated so far. For example, successive invasions of the Mediterranean fruit fly Ceratitis capitata (Medfly) during the 20th century in California have resulted in a loss of $60 \%$ of the ancestral allozyme genetic variation (Villablanca et al. 1998). Significant decreases in genetic variability of the source population have been reported in introduced areas, especially in plants (Eckert et al. 1996, Am- 
sellem 2000, Goodisman et al. 2001), insects (Berlocher 1984, Tsutsui et al. 2000), birds (Baker \& Moeed 1987) and molluscs (Selander \& Ochman 1983, Knight et al. 1987, Johnson 1988).

Interestingly, our data for Crepidula fornicata do not fit theoretical expectations for populations founded from a few individuals or empirical observations made for other exotic species. Throughout its original range, C. fornicata exhibits low genetic diversity (Hoagland 1984), which is close to the average observed heterozygosity found for 46 other mollusc species $\left(H_{0}=0.148\right.$; review in Nevo et al. 1984). Interestingly, the same level of gene diversity was also found within the introduced area in the present study. Similarly, Hoagland (1985) did not observe any decrease in genetic diversity in an analysis of 1 English population (Portsmouth) compared to native populations, except for the loss of some rare alleles. Moreover, no enhanced genetic differentiation was observed in the introduced area although repeated founding events are likely to increase genetic divergence among populations (Slatkin 1977). Indeed, local random drift associated with founder effects may amplify genetic heterogeneity during colonization. Studies of invasions have often shown an increase in genetic differentiation after introduction, as for the starling Sturnus vulgaris in New Zealand (Ross 1983), the land snail Theba pisana on Rottnest Island, Australia (Johnson 1988), and the walnut husk fly Rhagoletis completa in California (Berlocher 1984). Genetic data for C. fornicata thus do not fit any founder effect expectations and refute the hypothesis of persistent drift effects during the French invasion.

The high genetic diversity displayed by French populations fits well with the known history of Crepidula fornicata introduction on French coasts. Several introduction events were recorded (e.g. over the period between 1940 and 1970 and during the 1970s). In addition, the lack of difference in genetic diversity between French populations with different documented introduction dates is consistent with the hypothesis that most populations were established from multiple sources and also suggests that populations rapidly expanded after their establishment. Finally, the North populations (Gravelines and Port en Bessin) were genetically differentiated from all other French populations with exception of Bourgneuf, suggesting that at least 2 introductions occurred. These results are consistent with those of a study by Marsden et al. (1995) on the zebra mussel Dreissena polymorpha that has invaded eastern North America from Europe: i.e. zebra mussels in North America had the same high genetic variability as European populations. Like populations from Europe, D. polymorpha populations in North America were not highly differentiated, suggesting that founder populations were not small and/or frequent mixing occurred. It is noteworthy that the potential vectors (e.g. ballast water tanks, aquaculture) of C. fornicata and D. polymorpha, both species with a pelagic stage, allow transportation of great numbers of individuals, thus making cryptic recurrent introductions more likely along with continual genetic mixing of established populations.

In addition to the introduction history, some biological features may explain the high level of genetic diversity observed, namely the reproductive system and the occurrence of a planktonic larval stage. Our result showed that the sex ratio of the French population was balanced. This is in agreement with in vivo experiments which showed that sex reversal (sequential protandrous hermaphroditism) in Crepidula fornicata is correlated with the maintenance of a 1:1 sex ratio (Hoagland 1978, Le Gall 1980). Moreover, Charnov (1982) demonstrated that no bias in sex ratio is expected in C. fornicata populations. He proposed that, under sex reversal, the sex ratio should be biased toward the first sex if neither of the 2 sexes loses fertility during growth. This is not the case for C. fornicata, in which size greatly limits mobility, which is an important factor for male reproduction but not for female (Coe 1936, Wilczynski 1955). This effect is also accentuated by the fact that female egg production increases with increasing size in molluscs. The lack of a sex ratio bias contributes to minimizing the genetic drift effects by maximizing the effective size of the population.

Altogether, the large majority of the populations analyzed seems to have already reached both genetic and demographic equilibrium. In only a few cases were gene diversity disequilibria observed. If the marginal values of the Wilcoxon-test for heterozygote deficiency at mutation-drift equilibrium are taken into consideration, 4 populations (Cancale, Bréhat, Morlaix and Fouras) are suspected to have been subjected to recent expansion. This result fits well with historical and field-based studies which proposed that these bays were recently (re)colonized. The bays of Cancale (since 1976) and Fouras (since 1972) are known to have undergone explosive recolonization after eradication trials (Sauriau et al. 1998, Blanchard \& Ehrold 1999). Bréhat and Morlaix bays are known to have undergone a recent population establishment during the last year, suggesting that these populations are now expanding.

During the invasion process, the lateral expansion of an established population (gradual dispersal) is generally associated with natural processes, but it can be increased by long-distance dispersal (jumping dispersal) from foreign sources via human activities (Sakai et al. 2001). Human activities (overfishing and transplantation) are known to play an important role in deplet- 
ing genetic differentiation between populations. For example, large importations of oyster spat from Norway to Scotland are responsible for the genetic mixing of Scottish and Nordic populations of Ostrea edulis (Johannesson et al. 1989). In Northern Europe, Hessland (1951) noted that apart from natural transport of Crepidula fornicata larvae, 'this species is also disseminated by the agency of man, especially in England and Denmark'. Consequently, the rapid expansion of $C$. fornicata along the French coastlines has been thought to be assisted by oyster transfers, a common practice by shell farmers between Atlantic and English Channel bays (M. Blanchard pers. comm.). In contrast, we found no strong genetic identity between Atlantic and Channel shellfish farming bays. The only exception was the Arcachon (Atlantic) population, which was genetically similar to 3 Channel populations. Such effect of human-mediated transportation was shown only in a few cases, for example between Arcachon and Sète or between Bourgneuf and the northern populations. The presence of $C$. fornicata within the lagoon of Thau (Sète) was the result of a massive transfer of Japanese oysters between the bays of Arcachon and Sète in 1982 (Blanchard 1995). According to Marteil (1963), the slipper limpet was accidentally introduced to the Pénerf River, close to Bourgneuf, with a transfer of blue mussels from the Netherlands, and was subsequently observed in 1963 in the Bourgneuf Bay (Marteil 1965). Thus, our data indicate human-mediated 'jump'-dispersal between some 'pairs' of populations. In the same way, allozyme variation in Atlantic and Mediterranean populations of Ostrea edulis suggests that the effects of extensive transplantations of oyster spats between areas are only detectable at specific localities, whereas larval dispersal patterns explain most of the genetic structure of this planktonic developer (Saavedra et al. 1993).

As noted by Hessland (1951) for Crepidula fornicata: 'Artificial dispersal contributed to the advance in certain cases but spontaneous spreading occurred independently at the same time'. C. fornicata produces long-lived planktotrophic larvae that spend 2 to $4 \mathrm{wk}$ in the plankton. Provided that gene flow is usually positively correlated with dispersal ability (Crisp 1978, Palumbi 1994), a lack of extensive genetic differentiation over a given range is expected for this species. The weak overall population differentiation of $C$. fornicata in France is in agreement with this hypothesis. Pairwise $\hat{\theta}$ values ranging from 0.001 to 0.085 and a global $\hat{\theta}$ value of 0.022 fall well within the range of $\hat{\theta}$ values reported by other allozyme studies of planktonic developers (Mitton et al. 1989, Benzie \& Williams 1992, Stiven 1992, Saavedra et al. 1993).

Limitations to the dispersal and subsequent gene flow of planktonic developers are mainly connected with habitat availability and hydrodynamic conditions (e.g. tidal residual currents, wind-driven currents, density currents, fronts and gyres: Pechenik 1999, Ellien et al. 2000) which sometimes act as invisible barriers to gene flow. For example, in the case of Ostrea edulis, hydrodynamic barriers restrict gene flow outwards from the Mediterranean Sea across the Straits of Gibraltar (Saavedra et al. 1993). In the present study, the genetic differentiation between the Channel and Atlantic groups illustrates the major role of residual currents at the western Channel entrance (Iroise Sea). Similarly, genetic differentiation between the Channel and North populations indicates that the Cotentin Peninsula (the peninsula between Cancale and Port en Bessin, see Fig. 1) may act as a biogeographical boundary that influences marine circulation and probably restricts gene flow between these 2 Channel areas. Also, larval dispersal seems to be limited by local gyres in Bourgneuf Bay (i.e. restricted to the Loire and the Vilaine estuaries since 1963). The pattern of isolationby-distance within the Channel group may also be due to such a process. To date, although the main watermass circulation pattern through the Channel forms an almost axial flux carrying propagules from the Atlantic towards the North Sea, some lateral gyres of various intensities are linked to coastal topography (Salomon \& Breton 1991). Thus, some strong gyres may play an important role in trapping larvae and, consequently, on the formation of the genetic structure of C. fornicata populations in the Channel.

In conclusion, the most striking result regarding the invasion by the slipper limpet in France is that the populations have not undergone a severe founder effect that would have reduced the genetic diversity compared to the native USA populations. Despite their recent introduction, the introduced populations are genetically and demographically similar to the native populations. Indeed, the majority of French populations did not exhibit any deviation from migration-drift equilibrium. A few cases (4 out of 12 populations) even showed an excess in heterozygotes, indicating a recent expansion that is probably due to eradication trials (at Cancale and Fouras) or to a new wave of colonization (at Bréhat and Morlaix). Altogether, both human-mediated action and hydrodynamic dispersal (through larval dispersal) are responsible for the actual genetic structure along the French coastline. However, the relative importance of these 2 factors in shaping gene flow in Crepidula fornicata needs to be investigated more precisely.

Acknowledgements. The authors are grateful to G. Bachelet, G. Brezellec, N. Cuvelier, P. Goulletquer, A. Langlade, C. Lemaire, J. L. Martin, X. de Montaudouin, G. Mouillard, M. Ropert and P. G. Sauriau for advice and/or help in collecting 
samples of Crepidula fornicata in France, and to K. H. Halanych for the American sample. This project was funded by the 2001 INVABIO program of the Ministère de l'Ecologie et du Développement Durable (MEDD; project no. D4E/SRP/ 01115), the PNEC — Site Atelier 'Baie du Mont St. Michel', the Centre National de la Recherche Scientifique (CNRS, ATIPE program) and the Bettencourt-Schueller Foundation (Coup d'élan 2001). L.D. was funded by a PhD grant from the Region Bretagne. This project also largely benefited from discussions with M. Blanchard (IFREMER, Brest) and J. Pechenick (Tufts University). The authors are also grateful to D. McGlashan and C. Engel for improvements to the manuscript.

\section{LITERATURE CITED}

Amos W, Balmford A (2001) When does conservation genetics matter? Heredity 87:257-265

Amsellem L, Noyer JL, Le Bourgeois T, Hossaert-Mckey M (2000) Comparison of genetic diversity of the invasive weed Rubus alceifolius Poir. (Rosaceae) in its native range and in areas of introduction, using amplified fragment length polymorphism (AFLP) markers. Mol Ecol 9: 443-455

Bachelet G, Cazaux C, Gantès H, Labourg PJ (1980) Contribution à l'étude de la faune marine de la region d'Arcachon. Bull Cent Etud Rech Sc Biarritz 13:45-64

Baker AJ, Moed A (1987) Rapid genetic differentiation and founder effect in colonizing populations of common mynas (Acridotheres tristis). Evolution 41:525-538

Barton NH, Charlesworth B (1984) Genetic revolution, founder effects, and speciation. Annu Rev Ecol Syst 15:133-134

Belkhir K, Borsa P, Goudet J, Chikhi L, Bonhomme F (2000) GENETIX 4.02, logiciel sous Windows TM pour la génétique des populations. Laboratoire Génome, Population, Interactions, Centre National de la Recherche Scientifique, UPR 9060, Université Montpellier II, Montpellier

Benzie JAH, Williams ST (1992) No genetic differentiation of giant clam (Tridacna gigas) populations in the Great Barrier Reef, Australia. Mar Biol 113:373-377

Berlocher SH (1984) Genetic changes coinciding with the colonisation of California by the walnut husk fly, Rhagoletis completa. Evolution 38:906-918

Blanchard M (1995) Origine et état de la population de Crepidula fornicata (Gastropoda Prosobranchia) sur le littoral français. Haliotis 24:75-86

Blanchard M (1997) Spread of the slipper limpet Crepidula fornicata (L., 1758) in Europe: current state and consequences. Sci Mar 61:109-118

Blanchard M, Ehrold A (1999) Cartographie et évaluation du stock de crépidules (Crepidula fornicata L.) en baie du Mont Saint-Michel. Haliotis 28:11-20

Carlton JT (1996) Pattern, process, and prediction in marine invasion ecology. Biol Conserv 78:97-106

Carlton JT (1999) Molluscan invasions in marine and estuarine communities. Malacologia 41:439-454

Carlton JT, Geller JB (1993) Ecological roulette: the global transport of nonindigenous marine organisms. Science 261:78-82

Charnov EL (1982) The theory of sex allocation. Princeton University Press, Princeton, NJ

Chauvaud L (1998) La coquille St Jacques en rade de Brest; un modèle biologique d'étude des réponses de la faune benthique aux fluctuations de l'environnement. $\mathrm{PhD}$ thesis, Université de Bretagne Occidentale, Brest

Coe WR (1936) Sexual phases in Crepidula. J Exp Zool 72: $455-477$
Coe WR (1938) Conditions influencing change of sex in mollusks of the genus Crepidula. J Exp Zool 77:401-424

Cole HA (1952) The American slipper limpet (Crepidula fornicata) on Cornish beds. Fish Invest Ser II 17:1-13

Collin R (1995) Sex, size, and position: a test of models predicting size at sex change in the protandrous gastropod Crepidula fornicata. Am Nat 146:815-831

Collin R (2001) The effects of mode of development on phylogeography and population structure of North Atlantic Crepidula (Gastropoda:Calyptraeidae). Mol Ecol 10: 2249-2262

Cornuet JM, Luikart G (1996) Description and power analysis of two tests for detecting recent population bottlenecks from allele frequency data. Genetics 144:2001-2014

Crisp DJ (1978) Genetic consequences of different reproductive strategies in marine invertebrates. In: Battalia $B_{\text {, }}$ Beardmore JA (eds) Marine organisms: genetics, ecology and evolution. Plenum Press, New York, p 257-273

Davies N, Villablanca FX, Roderick GK (1999) Determining the source of individuals: multilocus genotyping in nonequilibrium population genetics. Trends Ecol Evol 14: $17-21$

de Montaudouin X, Audemard C, Labourg PJ (1999) Does the slipper limpet (Crepidula fornicata, L.) impair oyster growth and zoobenthos biodiversity? A revisited hypothesis. J Exp Mar Biol Ecol 235:105-124

Dupouy H, Latrouite D (1979) Le développement de la crépidule sur le gisement de coquilles Saint-Jacques de la baie de Saint-Brieuc. Sci Pêche 292:13-22

Eckert CG, Manicacci D, Barrett SCH (1996) Genetic drift and founder effect in native versus introduced populations of an invading plant, Lythrum salicaria (Lythraceae). Evolution 50:1512-1519

Ellien C, Thiebaut E, Barnay AS, Dauvin JC, Gentil F, Salomon JC (2000) The influence of variability in larval dispersal on the dynamics of a marine metapopulation in the eastern Channel. Oceanol Acta 23:423-442

Erhold A, Blanchard M, Auffret JP, Garlan T (1998) Conséquences de la prolifération de la crépidule (Crepidula fornicata) sur l'évolution sédimentaire de la baie du MontSaint-Michel (Manche, France). CR Acad Sci, Paris Earth Planet Sci 327:583-588

Excoffier L, Smouse P, Quattro J (1992) Analysis of molecular variance inferred from metric distances among DNA haplotypes: application to human mitochondrial DNA restriction data. Genetics 131:479-491

Ferriere R, Belthoff JR, Olivieri I, Krackow S (2000) Evolving dispersal: where to go next. Trends Ecol Evol 15:5-7

Fisher RA (1954) Statistical methods for research workers, 12 th edn. Oliver \& Boyd, Edinburgh

Geller J (1996) Molecular approaches to the study of marine biological invasions. In: Ferraris JD, Palumbi SR (eds) Molecular zoology: advances, strategies, and protocols. WileyLiss, New York

Goodisman MAD, Matthews RW, Crozier RH (2001) Hierarchical genetic structure of the introduced wasp Vespula germanica in Australia. Mol Ecol 10:1423-1432

Guo SW, Thompson EA (1992) Performing the exact test of Hardy-Weinberg proportion for multiple alleles. Biometrics 48:361-372

Hamon D (1996) Peuplements benthiques des fonds meubles: distribution de la faune benthique-distribution de la crépidule (Crepidula fornicata). In: Augris C, Hamon D (eds) Atlas thématique de l'environnement marin en Baie de Saint-Brieuc. Institut Français de Recherche pour l'Exploitation de la Mer (IFREMER), Brest, p 46-71

Hartl DL, Clark AG (1997) Principles of population genetics. 
Sinauer Associates, Sunderland, MA

Hedrick PW (2000) Genetics of populations. Jones \& Bartlett, Boston, MA

Heller J (1993) Hermaphroditism in molluscs. Biol J Linn Soc 48:19-42

Hessland I (1951) Notes on Crepidula fornicata further invasion of Europe. Arkiv Zool 2:525-528

Hoagland KE (1978) Protandry and the evolution of environmentally-mediated sex change: a study of the mollusca. Malacologia 17:365-391

Hoagland KE (1984) Use of molecular genetics to distinguish species of the gastropod genus Crepidula (Prosobranchia: Calyptraeidae). Malacologia 25:607-628

Hoagland KE (1985) Genetic relationships between one British and several North American populations of Crepidula fornicata based on allozyme studies (Gastropoda: Calyptraeidae). J Molluscan Stud 51:177-182

Johannesson K, Rödström EV, Aase H (1989) Low genetic variability in Scandinavian populations of Ostrea edulis L.- possible causes and implications. J Exp Mar Biol Ecol 128:177-190

Johnson MS (1988) Founder effects and geographic variation in the land snail Theba pisana. Heredity 61:133-142

Knight AJ, Hughes RN, Ward RD (1987) A striking example of the founder effect in the mollusc Littorina saxatilis. Biol J Linn Soc 32:417-426

Lazure P, Salomon JC (1991) Etude par modèles mathématiques de la circulation marine entre Quiberon et Noirmoutier. Oceanol Acta (Spec Issue) 11:93-99

Lee CE (2002) Evolutionary genetics of invasive species. Trends Ecol Evol 17:386-391

Le Gall P (1980) Etude expérimentale d'association en chaîne et de son influence sur la croissance et la sexualité chez la crépidule (Crepidula fornicata Linné, 1758). PhD thesis, Faculté des Sciences de Caen

Levine JM, D'Antonio CM (1999) Elton revisited: a review of evidence linking diversity and invasibility. Oikos 87:15-26

Lodge DM (1993) Biological invasions: lessons for ecology. Trends Ecol Evol 8:133-137

Lubet P, Le Gall P (1972) Recherches preliminaires sur la structure des populations de Crepidula fornicata, mollusque gastéropode. Bull Soc Zool Fr 97:211-212

Luikart G, Allendorf FW, Cornuet JM, Sherwin WB (1998) Distortion of allele frequency distributions provides a test for recent population bottlenecks. J Hered 89:238-247

Marsden JE, Spidle A, May B (1995) Genetic similarity among zebra mussel populations within North America and Europe. Can J Fish Aquat Sci 52:836-847

Marteil L (1963) La crépidule (Crepidula fornicata L.) en France. Sci Pêche 121:1-6

Marteil L (1965) Extension de l'aire géographique de Crepidula fornicata L. pendant l'année 1964. Sci Pêche 135:5-6

Maruyama T, Fuerst PA (1984) Population bottlenecks and nonequilibrium models in population genetics. I. Allele numbers when populations evolve from zero variability. Genetics 108:745-763

Mitton JB, Berg CJ Jr, Orr KS (1989) Population structure, larval dispersal, and gene flow in the queen conch, Strombus gigas, of the Caribbean. Biol Bull 177:356-362

Moyle P, Light T (1996) Fish invasions in California: do abiotic factors determine success. Ecology 77:1666-1670

Nei M, Kumar S (2000) Molecular evolution and phylogenetics. Oxford University Press, New York

Nei M, Maruyama T, Chakraborty R (1975) The bottleneck effect and genetic variability in populations. Evolution 29: $1-10$

Neigel JE (1997) A comparison of alternative strategies for estimating gene flow from genetic markers. Annu Rev Ecol Syst 28:105-128

Nevo E, Beiles A, Ben-Shlomo R (1984) The evolutionary significance of genetic diversity: ecological, demographic and life history correlates. Lecture Notes Biomaths 53:13-213

Palumbi SR (1994) Reproductive isolation, genetic divergence, and speciation in the sea. Annu Rev Ecol Syst 25:547-572

Pechenik JA (1999) On the advantages and disadvantages of larval stages in benthic marine invertebrate life cycles. Mar Ecol Prog Ser 177:269-297

Pechenik JA, Hammer K, Weise C (1996) The effect of starvation on acquisition of competence and post-metamorphic performance in the marine prosobranch gastropod Crepidula fornicata (L.). J Exp Mar Biol Ecol 199:137-152

Pechenik JA, Gleason T, Daniels D, Champlin D (2001) Influence of larval exposure to salinity and cadmium stress on juvenile performance of two marine invertebrates (Capitella sp. I. and Crepidula fornicata). J Exp Mar Biol Ecol 264:101-114

Raymond M, Rousset F (1995a) GENEPOP (version 1.2): population genetics software for exact tests and ecumenicism. J Hered 86:248-249

Raymond M, Rousset F (1995b) An exact test for population differentiation. Evolution 49:1280-1283

Reise K, Gollasch S, Wolff WJ (1999) Introduced marine species of the North Sea coasts. Helgol Meeresunters 52: $219-234$

Rice WR (1989) Analysing tables of statistical tests. Evolution 43:223-225

Ross HA (1983) Genetic differentiation of starling (Sturnus vulgaris: Aves) populations in New Zealand and Great Britain. J Zool (Lond) 201:351-362

Rousset F (1997) Genetic differentiation and estimation of gene flow from F-statistics under isolation by distance. Genetics 145:1219-1228

Ruiz GM, Carlton JT, Grosholz ED, Hines AH (1997) Global invasions of marine and estuarine habitats by nonindigenous species: mechanisms, extent, and consequences. Am Zool 37:621-632

Saavedra C, Zapata C, Guerra A, Alvarez G (1993) Allozyme variation in European populations of the oyster Ostrea edulis. Mar Biol 115:85-95

Sakai AK, Allendorf FW, Holt JS, Lodge DM and 11 others (2001) The population biology of invasive species. Annu Rev Ecol Syst 32:305-332

Salomon JC, Breton M (1991) Courants résiduels de marée dans la Manche. Oceanol Acta (Spec Issue) 11:47-53

Sauriau PG, Pichockiseyfried C, Walker P, DeMontaudouin X (1998) Crepidula fornicata L. (Mollusca, Gastropoda) in the Marennes-Oleron Bay: side-scan sonar mapping of subtidal beds and stock assessment. Oceanol Acta 21: 353-362

Schneider S, Roessli D, Excoffier L (2000) Arlequin (V2.0): software for population genetics data analysis. Genetics and Biometry Laboratory, Department of Anthropology, University of Geneva

Selander RK, Ochman H (1983) The genetic structure of populations as illustrated by molluscs. Isozymes 10:93-123

Simberloff D, Von Holle B (1999) Positive interactions of nonindigenous species: invasional meltdown? Biol Invasions $1: 21-32$

Slatkin M (1977) Gene flow and genetic drift in a species subject to frequent local extinctions. Theor Popul Biol 12: 253-262

Slatkin M (1993) Isolation by distance in equilibrium and nonequilibrium populations. Evolution 47:264-279

Sokal RR, Rohlf FJ (1995) Biometry, the principles and prac- 
tice of statistics in biological research, 3rd edn. WH Freeman, New York

Stiven AE (1992) Genetic structure in a population of the ribbed mussel Geukensia demissa (Dillwyn) in a North Carolina salt marsh tidal gradient. J Exp Mar Biol Ecol 164:31-44

Swofford DL, Selander RB (1989) BIOSYS-1: release 1.7-a computer program for the analysis of allelic variation in population genetics and biochemical systematics: user's manual. Illinois Natural History Survey, Champaign

Tsutsui ND, Suarez AV, Holway DA, Case TJ (2000) Reduced genetic variation and the success of an invasive species. Proc Natl Acad Sci USA 97:5948-5953

Editorial responsibility: Otto Kinne (Editor), Oldendorf/Luhe, Germany
Vermeij GJ (1996) An agenda for invasion biology. Biol Conserv 78:3-9

Villablanca FX, Roderick GK, Palumbi SR (1998) Invasion genetics of the Mediterranean fruit fly: variation in multiple nuclear introns. Mol Ecol 7:547-560

Weir BS, Cockerham CC (1984) Estimating F-statistics for the analysis of population structure. Evolution 38:1358-1370

Wilczynski JZ (1955) On sex behaviour and sex determination in Crepidula fornicata. Biol Bull 109:353-354

Williamson M (1996) Biological invasions. Chapman \& Hall, London

Wright S (1951) The genetical structure of populations. Ann Eugen 15:323-354

Submitted: August 26, 2002; Accepted: January 7, 2003

Proofs received from author(s): April 24, 2003 